\title{
$0 \mathbb{R} \boldsymbol{Y}$
}

Vol. XV No. 4

August 1980

\section{Notes and News}

The vicuna rescue operation in the Pampa Galeras reserve is an undoubted success story for Peru - but not, as had been feared, to the point of becoming a disaster, through having too many vicuna. How many vicuña in fact are there in Pampa Galeras? The figure supplied by the Peruvian

Vicuña

Survey by

Satellite? authorities and quoted on page 220 of the April Oryx was over 40,000 (from 1000 in 1965). Added to this was the fear that the habitat was being overgrazed, so that animals were dying off at an undue rate. Some conservationists have always been suspicious of the reported high numbers. So the International Federation for Animal Welfare, best known for its championship of Canadian harp seals, financed an aerial survey of Pampa Galeras by Dr Keith Eltringham, a Cambridge biologist and member of the FPS Council who is well known for his aerial surveys of African savanna animals. From a sample aerial count in early April, Dr Eltringham concluded that there are in fact only some $11,000-12,000$ vicuna in the reserve. This means that a cull on the basis of the 40,000 estimate could soon exterminate the Pampa Galeras population. In May the World Wildlife Fund, which had accepted the official figure on the basis of local investigation by Dr Archie Mossman and Major Ian Grimwood, and had approved the cull, retracted this and called for a halt. It is now essential that, despite the formidable difficulties, a full survey, not just a sample one, be made, for we must know how randomly the animals are distributed over the reserve before the Eltringham report can be fully evaluated. Ironically, the technical means for such a survey exist. Satellite surveillance now permits the US military authorities to detect even golf balls on golfing greens, but civilians are not allowed to use this technology. Conservationists should be pressing for this solution to this particular problem. It could help a lot of other problems too.

At its Annual General Meeting on July 9 the FPS accepted the recommendation of Council that flora should be included with fauna in its remit for protection and preservation. The Society will now be called the Fauna and Flora Preservation Society. The decision came after most of Oryx had gone to press, and the old initials still occur. 
The Convention on Trade in Endangered Species (CITES) is one of the most important and successful weapons that conservationists have produced. Over 60 nations now subscribe to it, and it is beginning to bite. The Convention works through its schedules: all endangered species in The trade are on Schedule I or II: all trade is forbidden for Changing those on I, licences are needed for those on II. Clearly CITES enforcement is the big problem, and CITES works better in some countries, for example the USA, than others, for example the UK - see the item on page 354. But the situation in the administration of the Convention is changing, as Peter Sand, Secretary General of CITES, pointed out at an SSC meeting recently. From being a conservationists' measure, originating from the SSC, CITES is now an instrument of governments, involving bureaucrats and diplomats, and conservationists have to think carefully about tactics. Clearly it is vital that conservationists continue to play a major part if it is not to be at the mercy of political influences. By the end of 1980 Peter Sand expects all major wildlife importing countries and a large majority of exporters to have ratified CITES; the situation will then change from one where a few members try to control the outsiders to one where outsiders will find their products rejected and enforcement will be standardised. There are implications too in the fact that increasingly the Convention will be controlled by Third World countries for, in the main, they are the major wildlife exporters.

At the end of last year the Council for Nature in the UK expired, as reported in the last Oryx (April), page 221. Almost immediately a successor body arose phoenix-like out of its ashes. This is the Wildlife Link Committee of CoEnCo (the Council for Environmental Conservation), which New
Wildlife
Link itself has taken on the publication of habitat and various other CfN functions. Wildlife Link, under the able and experienced chairmanship of Lord Melchett, has a much wider membership than the body it replaces, including both amenity and animal welfare societies. Its main remit is wildlife conservation, and it will not in fact deal with purely amenity or purely welfare matters, but it is important that the amenity and welfare dimensions of wildlife conservation should be dealt with alongside the purely biological ones. Wildlife Link will be largely concerned with the relations between its members and various government bodies, from the Department of the Environment sideways and downwards. It has already taken over a number of $a d$ hoc groups of societies, which force of circumstances had brought into being in the past two or three years; and subcommittees will deal with whales and whaling, international trade in endangered animals and plants, and the Wildlife and Countryside Bill expected to be laid before Parliament in the autumn; the CfN Grey Seals Group has also become a Wildlife Link subcommittee. This rationalisation is much to be welcomed, and FPS can claim to have helped the development along at one or two crucial points. 
'The World Conservation Strategy will only work if it is accepted and supported and believed in by people', said David Attenborough at the UK launching of the plan. Otherwise it will have 'as much effect as throwing a pebble over Beachy Head'. He believed that people today

\section{A Pebble Over}

Beachy Head? do care, not just for selfish reasons but because they believe that the natural world is not just theirs to pillage. So the next step is for 'ordinary people' to bring irresistable pressure on politicians and all in authority to press for the right policies. 'Mankind has shown that it can do almost anything if it wants to badly enough. Put men on the moon? Certainly . . . Surely when the issue is so clear, when the facts are incontrovertible and the conclusions inescapable . . . when the penalty of failure is global disaster - surely humanity will want to collaborate and make sure that sanity prevails.' But is the issue so clear? Do most people see the facts as 'incontrovertible' and the conclusions as 'inescapable'? If not conservationists must see that they do - and quickly.

Five plants listed as extinct in the plant Red Data Book published last year have turned up in botanic gardens, the Threatened Plants Committee (TPC) reports. These include Easter Island's only tree Sophora toromiro, which, thanks to introduced sheep, was reduced to one tree by Easter 1917 and none in 1962. However, Thor Heyerdahl during Island Tree his visit in the ' 50 s had collected seeds and sent them to the Saved Göteborg Botanical Garden in Sweden, and three that germinated have survived. The TPC is planning to return them to their native island. Another is Bromus interruptus, a small British grass discovered as recently as 1840 , which flourished locally as a weed in fields of sainfoin, rye grass and clover, decreased rapidly with improved seed-cleaning methods until reduced to one site in Cambridgeshire by 1970 and was not seen after 1972. This has been discovered in the Edinburgh Botanic Garden, where the botanist who had been working on it had no idea his were the only specimens. It has now been distributed to other botanic gardens and reintroduction is possible, though as a field weed perhaps more difficult.

India's Andaman and Nicobar Islands in the Bay of Bengal, running in a north/south chain from 100 miles south of Burma to a point 80 miles north of Sumatra, have until recently preserved some of the richest rain forest in the world, writes our FPS Consultant Anne Wright in

Destruction Hornbill. Now it is being rapidly destroyed both as a result in the Andamans of settlement - new settlers are coming into the islands at the rate of 1000 a month - which cannot be controlled, and forestry plans that provide for the clearance of large areas of native forest to make way for plantations of commercially viable woods. This was done some ten years ago when teak was planted and has proved useless. The islands have a very thin topsoil which washes away immediately in the 
heavy monsoon rain: another conservationist, Humayun Abdulali, writes in the Bombay NHS fournal that 'one can see the soil being washed into the sea and the denuded areas being turned into barren land'. He quotes a study in Brazil which showed that whereas a hectare of tropical rain forest normally lost a kilo of soil a year in erosion, 13 tons were lost annually after deforestation. Both writers point to the serious hunting of wildlife, despite protection. Settlers hunt the turtles, deer and the endemic Andaman wild pig, on which the native tribal people depend - also crocodile and dugong, and even the endangered Andaman teal in remote places. A Task Force to study the islands' ecology and advise on land use is urgently needed, even though earlier reports, including an IUCN one in 1976, have made recommendations without result.

After much pressure from conservationists over a number of years, the Kashmir Government has at last removed the experimental sheep breeding station from the Dachigam Sanctuary where the only sizeable population of the Kashmir stag, the hangul Cervus elaphus hangul, survives Good News rather precariously. The sheep station was a serious
for the Hangul according to a 1974 expedition from Cambridge, with large numbers of cattle and other domestic animals (which grazed in the sanctuary) to supply the staff. Villagers from outside were also allowed recently to graze large numbers of buffalo and sheep in the sanctuary. And winter feed for the station's sheep (of which there were some 2700 in 1974, but over 5000 by 1978) consisted of herbage cut in the sanctuary. In 1977 deer numbers in the sanctuary were about 250 and none had been recently sighted outside. Hopefully, the departure of the sheep farm will be the first step in implementing the management plan and the end of all grazing by domestic animals. If so the deer should be able to build up numbers to a satisfactory level.

The last known habitat of the lion-tailed macaque monkey and the last surviving area of untouched tropical forest in South India, the Silent Valley in Kerala, seems to be doomed. The plan to build a dam to flood the valley for hydroelectric power looks like becoming a reality. Indian Battle for
India's
Silent Valley conservationists, who have suggested other suitable sites, pointed out that Kerala actually has a surplus of power and that this 9000 -ha forest is a priceless gene pool with unique animals and plants as yet unstudied. After a long battle the scheme was sanctioned by the State Planning Commission back in 1971 during which objections and protests have been heard from all over India and many parts of the world, and Mrs Gandhi herself has intervened, the Kerala Government, while reiterating its determination to build the dam, has agreed to consider alternative plans, including a most comprehensive development plan put forward by the Secretary of the Ministry of Agriculture in New Delhi, Dr Swaminathan. This would include the Silent Valley (so-called because 
there are no cicadas) in a National Rainforest Biosphere Reserve, getting the electricity by other means and creating employment with new industries. The lessons of the nearby Idukki Dam in Kerala are very relevant to the Silent Valley plans. There the loss of the trees resulted in soil being washed away by the monsoon rains and a change of climate. Where before the forest had moderated the heat and trapped the rainwater, allowing it to soak in slowly, now the heat is intense, and, as one farmer said, 'The wells and ponds dry up in the summer. They did not do that before the dam was built.'

Grevy's zebra Equus grevyi do not occur permanently in substantial numbers in any existing game reserve or national park, says Dr Hans Klingel, and to ensure the species's survival it is essential either to create a new reserve for them or enlarge an existing one to fit their requirements.

\section{Grevys Need More} Protection Population estimates have varied greatly in recent years in Kenya from 1500 to 13,000 - but the trend downwards is inescapable and the main cause is poaching for their attractive skin with its narrow stripes which is much in demand. In Ethiopia in 1978 the population total was under 1500, with poaching pressure 'heavy and increasing'. In Somalia, where Grevys were once numerous, not one was seen in a 1976 survey, suggesting they may be extinct there, again due to poaching, as domestic stock did not compete for their grazing. Dr Klingel, who is Chairman of the SSC African Equids Group, points out that little is known about Grevy migration patterns and these need to be investigated before their protection requirements can be fully appreciated. Poaching pressure is off for the moment but with the near disappearance of rhinos it may return.

A very tentative estimate of the number of chimpanzees Pan troglodytes surviving in the 24 nations in tropical Africa where they have occurred is given by Geza Teleki and Lori Baldwin in a Preliminary Assessment of wild populations. Their data, as they emphasise, are in almost

Disaster for

Chimpanzees every case 'spuriously precise' and much more field work is needed. They estimate chimpanzee numbers in known habitats to be at best under 17,500 , of which not many more than $\mathbf{4 0 0 0}$ are breeding females. In areas they call 'potential habitat' (and they emphasise the tentativeness of this) they suggest some 17,800 , with perhaps 4280 breeding females. This puts the maximum total in all possible habitats at some 35,000 . Such a figure they suggest, if confirmed, ought to mean a complete stop on international trade in chimpanzees which, they say, has done more to reduce numbers than any other single factor, although habitat destruction, logging and hunting have contributed. At a conservative estimate, they suggest that in recent years 1500-8000 chimpanzee infants have been sent out of Africa every year, mainly to the USA and Japan, for laboratory use. And the toll in animals killed to get 
the infants must have considerably exceeded these numbers. They accept that some of the research for which these animals are used is valuable, but they urge very strongly that unnecessary damage and waste should be stopped by the application of firm controls. And why should not lumber companies about to clear-fell a forest area and pharmaceutical research users collaborate? As it is, no matter how much lumbering is going on in chimpanzee habitat, overseas buyers continue to buy from local wildlife dealers who use unskilled trappers, who in turn go to undisturbed habitats if they can and probably kill four or five animals in order to get one young one. With this tale of destruction, it is not surprising that in four of the 24 countries (Gambia, Benin, Togo and Upper Volta) chimpanzees are extinct, and in the majority of the remainder they are described as 'declining' (5), 'possibly extinct' (3), 'probably extinct' (4) or 'virtually extinct' (2). In only one country, Tanzania, are they 'well protected'.

Swayne's hartebeest Alcelaphus buselaphus swaynei is a race that is being steadily eliminated. The total population is thought to be well under 1000 . However, a study of the main population on the Senkele Plains in southern Ethiopia has shown the animals to be in good condition Ethiopia's and breeding successfully, but the maximum number Dwindling counted was 440 . Despite the fact that the grasses they Hartebeest preferred were also heavily grazed by domestic stock, and cattle and hartebeest were frequently seen together, the study authors, J.G. Lewis and R.T. Wilson (whose report appears in Biological Conservation), found that there seemed to be 'a situation of competitive co-existence', helped by the fact that the cattle are not present in large numbers all the year round, and moreover are herded at night, giving a period which the hartebeest can take advantage of. But the outlook for the hartebeest is bleak. The increases in human population and domestic stock have drastically changed their environment since the turn of the century when Swayne could see 'immense herds' out on the open plains. Some animals have been able to adapt, but cultivation continues to encroach on their present habitat - in the $100 \mathrm{sq} \mathrm{km}$ study area only $58 \mathrm{sq} \mathrm{km}$ were available to the hartebeest - and their survival depends on political decisions for land use and development: in other words, whether or not the Ethiopians want them to survive.

An enquiry into why the golden eagles on the Scottish island of Rhum, a national nature reserve, have reared few young strongly suggests that the cause is contamination by toxic chemicals. No chemicals are of course used in the reserve, but seabirds are a major prey for the eagles in the Eagles Get breeding season, and it was noticeable that the eagles in Pesticides from the Sea the territory that produced fewest chicks also consumed the highest proportion of seabirds, especially fulmars; conversely those in the territory that produced most chicks took the lowest proportion of seabirds. On Eigg, too, one pair of golden eagles that feed substantially on fulmars have had poor success in recent years, 
FIVE ARABIAN ORYX, part of the World Herd, arrived by air in Oman last March from the San Diego Wildlife Park as the start of the operation to release them in the wild. Others will follow. The Oman Government has prepared a special holding pen where they can be acclimatised before release in the Jiddat al Harasis.

G.N. Wood

while a more successful pair, with no seabird colonies in their territory, prey on rabbits and sheep carrion. Seabirds are a main prey only during the breeding season - in winter they are away at sea - after the eagles have laid their eggs, and the investigator, P. Corkhill, in a paper in Scottish Birds, 11, 2, concludes that the poor breeding results may be a combination of toxic chemicals 'affecting both the hatchability of eggs and subtle changes in metabolism and behaviour of the eagles themselves'. As Rhum is the scene of the Nature Conservancy Council's experiment to reintroduce sea eagles the findings have considerable significance for them as well as for the golden eagles.

The Chinese People's Republic has signed an agreement with the World Wildlife Fund to establish a research station for the protection of the giant panda, and George Schaller, eminent American conservation scientist, is returning to China to set up the long-term research China, programme in co-operation with Chinese scientists and the Panda and naturalists. In June this year Dr Schaller, along with the Horse WWF Chairman Sir Peter Scott, visited the 200,000-ha Wolong reserve, established in 1975 by the Chinese Government to protect the pandas, where the research station will be. This is in Sichuan (Szechuan), in western China. The programme, which will include captive breeding, has become urgent because bamboos, the panda's staple food, are dying off in many areas. The pandas live in dense bamboo forests at high altitudes, and are not likely to be easy to study. A survey in 1973 put numbers in the wild as low as between 400 and 1000 - a very low number if 
there is a food shortage. A much rarer animal than the giant panda which China may be able to rescue is the Przewalski's horse, which once ranged widely over the high mountainous Sino-Mongolian frontier. It is now extinct in the USSR, and Mongolians believe it to be so on their side also, but a message from the President of the Chinese Academy of Sciences, Dr Fang Yi, says that local people in the Zhun Ge Er basin in Sinkiang report seeing the horse, and Chinese scientists are going to investigate on the spot. It would be good news indeed if the reports proved correct and China is prepared to protect the horse in the large areas that it needs.

\section{FPS Wildlife Tours}

Dr Alison Jolly, a Council member, authority on lemurs and author of Lemur Behaviour, will lead a tour in Madagascar, Réunion and Mauritius, November 17-December 7. This will include excursions to Perinet Reserve in the eastern rain forests of Madagascar to see indri and other lemurs; Berenty reserve in the arid zone, with more lemurs; and Nossi Bé island. Three nights in Réunion are followed by five nights in Mauritius, with visits to Round Island and the Black River gorges, habitat of the Mauritius kestrel and pink pigeon.

A tour of the Falkland Islands and the Valdes Peninsula in Argentina, December 13-January 2, will be led by Roger Perry MA FRGS, specialist in South American wildlife conservation and former director of the Charles Darwin Research Station in the Galapagos for six years. The itinerary includes some of the spectacular seabird colonies, with king, rockhopper, Magellan and gentoo penguins, black-browed albatrosses, and king and rock shags, and also fur seals and sealions. Valdes, the best locality in Argentina for wildlife, has elephant seals, sealions, guanacos and Darwin's rhea, and offshore breeding places for the rare humpback whales.

Dr James O. Juvik, FPS Hawaii consultant and associate professor of geography at the University of Hawaii, will lead a tour of the Hawaiian Islands, January $12-28,1981$, which will include viewing of humpback whales and excursions to several sites of endemic land birds, seabird nesting areas, and green and hawksbill turtle beaches. Many parts are wonderfully spectacular and still unspoiled, and birdwatchers can be sure of the iwi, apapane and amakihi, or honeycreeper.

Full details from FPS, c/o The Zoo, Regent's Park, London NW1 4RY.

\section{Przewalski Horse Plans}

Breeding the Przewalski horse in increasing numbers to provide a stock for possible reintroduction into the wild has been urged by successive Przewalski Horse Symposia. This policy was reiterated both by the recent Symposium held in Winchester in June, and by the first meeting of the SSC Przewalski Horse Captive Breeding Group, which immediately preceded it at Marwell Zoological Park, under the chairmanship of Professor Veselovsky of Prague. The ultimate aim is to set up reserves in Central Asia, where the captive animals can be acclimatised to life in the wild. In the meantime it is proposed to set up breeding groups from the widest possible genetic origins, coupled with an international stallion exchange, to provide stock for these reintroductions. The authorities of the USSR are to be asked to cooperate in this, and both the San Diego Wild Animal Park and the Minnesota Zoo have offered foals to the project. 